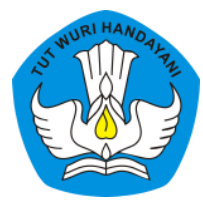

Page: 887-906

\title{
PEMBELAJARAN BLENDED LEARNING BERBASIS WHATSAPP DALAM PELAKSANAAN EKSTRAKURIKULER KEAGAMAAN PADA MASA PANDEMI COVID-19
}

\author{
Yulianto \\ Sekolah Dasar Negeri Sembungan, Bantul, Daerah Istimewa Yogyakarta, Indonesia \\ Contributor Email: yulee7tujuh@gmail.com
}

Article Url: https://ojsdikdas.kemdikbud.go.id/index.php/didaktika/article/view/356

\begin{abstract}
Learning during the Covid-19 pandemic did not allow face-to-face implementation. The Ministry of Education and Culture issued circular number 4 of 2020 concerning home learning (belajar dari rumah/ BDR). The limitations that teachers have in mastering information technology are an obstacle in implementing bdr. lack of mobile phone facilities (gadgets) is another problem in implementing bdr. This obstacle is the main problem in implementing religious extracurricular activities. This problem is overcome by the application of WhatsApp-based blended learning. with the involvement of colleagues, the mastery of information technology for learning is increasing. teachers are not tech-savoy. Finally, the implementation of bdr in the implementation of religious extracurricular activities can run well.
\end{abstract}

Keywords: Home Learning, Blended Learning, Religious Extracurricular Activities. 


\begin{abstract}
Abstrak
Pembelajaran di masa Pandemi Covid-19 tidak memungkinkan dilaksanakan secara tatap muka. Kementerian Pendidikan dan Kebudayaan mengeluarkan Surat Edaran Nomor 4 Tahun 2020 tentang Pembelajaran di Rumah (BDR). Keterbatasan yang dimiliki oleh guru dalam penguasaan teknologi informasi menjadi kendala dalam pelaksanaan BDR. Kekurangan sarana telepon genggam (gawai) juga merupakan masalah lain dalam pelaksanaan BDR. Kendala ini menjadi permasalahan utama dalam pelaksanaan ekstrakurikuler keagamaan. Permasalahan ini diatasi dengan penerapan blended learning berbasis WhatsApp. Dengan keterlibatan teman sejawat penguasaan teknologi informasi untuk pembelajaran semakin meningkat. Guru menjadi tidak gagap teknologi. Akhirnya pelaksanaan BDR ekstrakurikuler keagamaan dalam dapat berjalan dengan baik.
\end{abstract}

Kata Kunci: Belajar di Rumah; Blended Learning; Ekstrakurikuler Keagamaan.

\title{
A. Pendahuluan
}

Jumlah Guru di Sekolah Dasar Negeri Sembungan ada 8 orang yang terdiri dari guru kelas 6 orang dan guru mapel 2 orang. Dari 8 orang guru tersebut $90 \%$ guru sudah memasuki usia 50 tahun bahkan ada yang hampir purnatugas. Di samping itu, mereka juga kurang menguasai Teknologi Infomasi. Dalam praktik pembelajaran mereka masih cenderung untuk menggunakan pembelajaran yang bersifat konvensional. Mereka lebih banyak menggunakan menggunakan metode ceramah. Di sisi lain implementasi Kurikulum 2013 lebih menuntut untuk menerapkan teknologi informasi walaupun bersifat sederhana. Suyono (2017: 186) menyebutkan bahwa seorang guru yang profesional harus menguasai kompetensi profesional tersebut. Salah satu kompetensi adalah kemampuan menguasai pengetahuan bidang ilmu pengetahuan, teknologi atau seni dan budaya sesuai dengan bidang studi atau mata pelajaran yang diampunya. Keadaan ini merupakan kendala bagi pelaksanaan pembelajaran jarak jauh yang diterapkan oleh pemerintah.

Masa pandemi Covid-19 pemerintah khususnya Kementerian Pendidikan dan Kebudayaan mengeluarkan kebikan melalui Surat Edaran Menteri Pendidikan dan Kebudayaan Nomor 4 Tahun 2020 menetapkan pembelajaran di rumah. Pembelajaran Jarak Jauh yang diterapkan yaitu Belajar di Rumah (BDR). BDR ini menuntut kemampuan guru untuk menguasai pembelajaran daring maupun luring. Keadaan ini berusaha untuk diatasi dengan pelibatan 
teman sejawat. Teman sejawat dilibatkan untuk menjadi tutor sebaya kepada rekan guru lain. Harapannya, dengan pelibatan teman sejawat lebih efektif dan tepat sejalan dengan pendidikan andragogi.

Peraturan Bupati Kulon Progo Nomor 65 Tahun 2017 menetapkan ekstrakurikler wajib. Ekstrakurikuler wajib yang ditetapkan Pemerintah Kabupaten Kulon Progo meliputi ekstrakurikuler wajib keagamaan, pengamalan Pancasila, Pramuka, dan pengenalan budaya Kemataraman. Pada masa pandemi Ccovid-19, tidak semua kegiatan ekstrakurikuler wajib tersebut dapat dilaksnakan. Ekstrakurikuler wajib yang tetap dijalankan yaitu ekstrakurikuler keagamaan menginngat kegiatan tersebut dibiayai dengan dana APBD Kabupaten Kulon Progo.

Keadaan pandemi Covid-19 menuntut kemampuan kepala sekolah untuk menentukan teknik pelaksanaan kegiatan ekstrakurikuler keagamaan tersebut. Kebijakan yang ditentukan harus dapat diterima dan dilaksanakan oleh semua warga sekolah, baik itu guru, tenaga kependidikan, siswa, maupun orang tua siswa. Setelah melakukan kajian, kegiatan ekstrakurikuler keagamaan dilaksanakan dengan blended learning.

Kepala Sekolah harus mampu mengelola manjemen pendidikan dengan baik. Mulyasa (2009: 7) menyebutkan bahwa menajemen pendidikan adalah suatu kegiatan yang merupakan proses pengembangan yang dilakukan secara kerjasama oleh sekelompok orang untuk mencapai tujuan pendidikan yang sudah ditentukan sebelumnya. Kegiatan manajemen pendidikan tersebut mencakup kegiatan perencanaan, pengorganisasian, pergerakan, dan pengawasan. Dalam kaitannya dengan pelaksanaan kegiatan ekstrakurikuler keagamaan ini diperlukan pula tahapan perencanaan dari sekolah untuk menentukan arah dan tujuan, pengorganisasian yaitu dengan pembentukan paguyuban, pergerakan yaitu komunikasi interaktif antara guru, orang tua, dan eavaluasi dari kegiatan ekstrakurikuler itu sendiri.

Chaeruman (2013) menyebutkan bahwa pembelajaran blended learning memosisikan pembelajaran online sebagai tahapan atau langkah yang tidak terpisahkan atau menyatu dari pembelajaran secara keseluruhan. Jadi pembelajaran online bukan bagian tersendiri dari rangkaian proses pembelajaran, 
melainkan merupakan kesatuan yang utuh. Blended learning merupakan kombinasi antara pembelajaran secara daring maupun luring. Jadi pembelajaran daring maupun luring tidak berdiri sendiri.

Rumusan masalah dalam penelitian ini adalah bagaimanakah pembelajaran blended learning berbasis whatsapp dapat mengatasi permasalahan pelaksanaan ekstrakurikuler keagamaan dalam masa pandemi covid-19 di SD Negeri Sembungan. Tujuan penelitian ini adalah untuk mengetahui pembelajaran blended learning dapat mengatasi permasalahan pelaksanaan kegiatan ekstrakurikuler keagamaan di SD Negeri Sembungan di masa pandemi Covid-19.

Manfaat dari penelitian ini dengan pelaksanaan blended learning dapat mengatasi permasalahan pelaksnaan ekstrakurikuler keagamaan di SD Negeri Sembungan dalam masa pandemi Covid-19.

\section{B. Metode}

Cara pemecahan masalah yang digunakan dalam karya ilmiah ini yaitu penerapan metode pembelajaran blended learning dengan pelibatan Teman Sejawat. Adapun teknik pengumpulan data yang digunakan dalam penelitian ini adalah dengan observasi. Pengamatan dilaksanakan pada bulan Juli s.d September 2020. Yang menjadi subjek penelitian guru SD Negeri Sembungan yang berjumlah 8 orang.

Instrumen pengumpulan data yang dilakukan adalah dengan menggunakan angket, wawancara, dan dokumentasi. Wawancara dilakukan dengan melibatkan semua guru SD Negeri Sembungan. Wawancara difokuskan pada pelaksanaan kegiatan ekstrakurikuler keagamaan dan masalah-masalah yang berkaitan dengan kesulitan yang mereka hadapi dalam pelaksanaan BDR khususnya dalam pelaksanaan ekstrakurikuler keagamaan. Wawancara juga dilakukan terhadap beberapa wali murid tentang kendala yang dihadapi mereka selama membimbing putra-putrinya selama pembelajaran BDR. Data dan dokumentasi diperoleh dari screenshoot fitur WhatsApp yang memuat pelaksanaan BDR ekstrakurikuler keagamaan selama pandemi Covid-19. Selain itu data juga diperoleh dari hasil penilaian yang dilakukan oleh guru. 


\section{Yulianto}

\section{Hasil dan Pembahasan}

Pembelajaran di Rumah (BDR) di masa pandemi covid-19 merupakan suasana pembelajaran yang tidak diperhitungkan sebelumnya. Pembelajaran dalam situasi ini tanpa persiapan maupun perencanaan terlebih dahulu. Sebelum pandemi covid-19 pembelajaran dilakukan dengan sistem tatap muka. Pada pembelajaran tatap muka interaksi sosial dapat dilakukan secara langsung. Dalam pembelajaran BDR interaksi tidak dapat dilakukan tatap muka secara langsung face to face. BDR menuntut penguasaan teknologi sebagai sarana utama.

Seameo Ceccep (2020) menyatakan BDR dapat dilakukan secara synchronous learning, asynchronous learning, maupun blended learning. Ketiganya tidak bisa lepas dari pemanfaatan teknologi informasi. Kita tahu bahwa guru dilahirkan pada abad ke-19 namun mereka mendidik dan mengajar siswa saat ini hidup di abad ke-20 dan mempersiapkan peserta didik yang akan menjalani kehidupan di abad ke-21. Situasi seperti ini jika tidak disikapi dengan bijak akan timbul kesenjangan yang sangat besar. Siswa atau peserta didik sudah akrab dengan HP android dengan segala fitur-fitur yang ada. Mereka sudah akrab dengan WhatsApp, Instagram, maupun Youtube. Keadaan ini bertolak belakang dengan kemampuan guru dalam penguasaan teknologi, khususnya teknologi informasi. Selama ini guru sebatas mengenal microsoft word (pengolah kata), excel (pengolah data), dan power point secara sederhana. Ketiga fitur itu digunakan sebatas untuk penyusunan perangkat pembelajaran, media, maupun pengolahan hasil belajara atau kegiatan lain yang bersifat administratif.

Memanfaatkan teknologi informasi dan komunikasi untuk berkomunikasi dan mengembangkan diri merupakan salah satu kompetensi profesional yang diamanatkan dalam Undang-undang Nomor 14 Tahun 2005 tentang guru dan dosen. Penguasaan kompetensi teknologi selaras dengan tuntutan pelaksanaan BDR yang menuntut penguasaan teknologi informasi baik untuk pelaksanaan pembelajaran daring maupun luring, serta campuran (blended learning). Pelaksanaan ekstrakurikuler keagamaan di SD Negeri Sembungan selama BDR menerapkan blended learning. Hal ini mengingat kemampuan penguasaan guru terhadap teknologi informasi yang masih 
rendah. Dengan rata-rata guru berusia 50 tahun ke atas. Bahkan ada yang sudah memasuki usia pensiun. Minat dan motivasi mereka untuk menggunakan teknologi informasi dalam pembelajaran sangat rendah. Keadaan ini diatasi dengan pelibatan teman sejawat yang mempunyai atau menguasai kompetensi teknologi informasi dalam pembelajaran.

Keterlibatan teman sejawat difokuskan untuk memberikan bimbingan teman guru lain. Bimbingan yang diberikan berupa pemanfaatan fiturfitur yang terdapat dalam WhatsApp. Belajar dengan teman sejawat akan lebih mudah. Hal ini sejalan dengan prinsip pembelajaran andragogi. Guru-guru akan merasa nyaman belajar dengan teman sejawat. Mereka merasa tidak digurui. Keakraban tercipta, sehingga memudahkan untuk membangun komunikasi maupun interaksi belajar mengajar.

Berdasarkan hasil angket diperoleh data bahwa tingkat punguasaan teknologi yang dimiliki oleh guru masih rendah. Penguasaan teknologi yang mereka kuasai masih terbatas untuk kegiatan bersifat administratif. Padahal pelaksanaan pembelajaran blended learning menuntut kemampuan penggunaan teknologi untuk pembelajaran. Kompetensi guru dalam penguasaan teknologi dapat dilihat pada tabel di bawah ini.

Tabel 1. Kompetensi Awal Guru dalam Penguasaan Teknologi Informasi

\begin{tabular}{cccccccc}
\hline \multirow{2}{*}{ No } & \multirow{2}{*}{ Nama Guru } & \multicolumn{5}{c}{ Kompetensi Yang Dikuasai } \\
\cline { 3 - 7 } & & Office & Excel & Power Point & Instagram & Whatsapp & Youtube \\
\hline 1 & Guru Kelas 1 & $\sqrt{ }$ & $\sqrt{ }$ & $\sqrt{ }$ & $\sqrt{ }$ & $\sqrt{ }$ & $\sqrt{ }$ \\
\hline 2 & Guru Kelas 2 & $\sqrt{ }$ & $\sqrt{ }$ & $\sqrt{ }$ & $\sqrt{ }$ & $\sqrt{ }$ & $\sqrt{ }$ \\
\hline 3 & Guru Kelas 3 & $\sqrt{ }$ & $\sqrt{ }$ & & & $\sqrt{ }$ \\
\hline 4 & Guru Kelas 4 & $\sqrt{ }$ & $\sqrt{ }$ & & $\sqrt{ }$ \\
\hline 5 & Guru Kelas 5 & $\sqrt{ }$ & $\sqrt{ }$ & $\sqrt{ }$ \\
\hline 6 & Guru Kelas 6 & $\sqrt{ }$ & & & $\sqrt{ }$ \\
\hline 7 & GuruPendidikan Agama & $\sqrt{ }$ & $\sqrt{ }$ & \\
\hline 8 & Guru PJOK & $\sqrt{ }$ & $\sqrt{ }$ & $\sqrt{ }$ \\
\hline
\end{tabular}

Belum meratanya kompetensi guru dalam penguasaan teknologi informasi menjadikan pelaksanaan BDR dalam kegiatan ekstrakurikuler keagamaan di SD Negeri Sembungan dilaksanakan dengan blended learning. Teknik blended learning yang digunakan dengan pemanfaatan aplikasi WhatsApp. WhatsApp dipilih karena fitur ini lebih familier dengan guru, siswa maupun wali murid. 
Pelaksanaan BDR tidak bisa lepas dari keterlibatan orang tua. Kegiatan pendampingan sangat diperlukan, karena tidak semua siswa terutama kelas rendah mampu menguasai aplikasi WhatsApp ini. Dalam pelaksanaan BDR banyak kendala yang dihadapi. Pertama, pertama,tidak semua siswa mempunyai HP android. Hal ini tentu saja merupakan kendala utama. Namun permasalahan ini dapat diatasi dengan cara orang tua datang ke sekolah untuk mengambil tugas yang diberikan oleh guru. Selain itu juga dengan cara guru datang ke rumah siswa untuk mengantar tugas yang harus dikerjakan oleh siswa. Guru melakukan kegiatan guru kunjung. Kedua, tidak semua orang tua wali mampu menggunakan aplikasi WhatsApp. Ketiga, orang tua juga kurang mempunyai waktu yang cukup untuk mendampingi siswa dalam mengerjakan tugas ekstra-kurikuler keagamaan selama BDR. Hal ini disebabkan banyak wali siswa yang bekerja sebagai buruh. Mereka bekerja sebagai buruh penambang pasir dan tenaga pembatik. Lingkungan sekolah merupakan daerah tambang pasir sekaligus sentra industri batik. Keempat, tidak semua wali siswa mempunyai kompetensi untuk memberikan bimbingan materi terlebih dalam kegiatan ekstrakurikuler keagamaan memerlukan keahlian khusus.

Materi keagamaan seperti tajwid, harokat, maupun cara pelafalan huruf Al-Qur'an dengan benar menyulitkan wali murid. Wali murid tidak semua memiliki kompetensi tersebut. Permasalahan ini diatasi dengan adanya komunikasi antara guru dan wali murid. Komunikasi dilaksanakan dengan memanfaatkan grup WhatsApp paguyuban di setiap kelas. Jika wali mengalami kesulitan, mereka dapat berkonsultasi dengan guru sehingga permasalahan dapat diminimalisir dan diatasi. Guru dapat memberikan contoh-conyoh pelafalan dengan memanfaatkan salah satu fitur WhatsApp yaitu dengan mengunggah video. Video pembelajaran yang diunggah merupakan video yang dibuat dan direkam oleh guru sendiri, namun guru juga dapat memanfaatkan video-video pembelajaran yang sudah ada; Keempat, belum semua guru menguasai fitur-fitur dalam WhatsApp Fitur WhatsApp yang digunakan dalam pembelajaran ini seperti percakapan (chat), unggah/ kirim gambar/ vidio, dan panggilan suara maupun video 
call. Pada fitur chat dijadikan sarana bagi guru dan peserta didik untuk melakukan komunikasi maupun interaksi dalam pembelaajran. Guru dapat menyampaikan materi maupun pemberian tugas kepada siswa. Sebaliknya siswa dapat mengajukan pertanyaan maupun meberikan jawaban pertanyaan dari guru. Fitur kirim gambar atau video. Melalui fitur ini guru dapat mengirimkan materi berupa gambar, dokumen maupun video pembelajaran. Fitur panggilan suara maupun video call akan memberikan kemudahan bagi guru maupun siswa untuk berineraksi secara langsung. Interaksi dapat berupa suara maupun suara dan gambar. Permasalahan ini diatasi dengan melibatkan teman sejawat yang mempunyai kompetensi TI yang lebih baik.

Pelibatan teman sejawat untuk belajar bersama pemanfaatan fitur whatsapp akan lebih efektif. Guru selaku manusia pembelajar juga butuh mengupdate pengetahuannya. Perkembangan ilmu penegtahuan dan teknologi yang begitu pesat tanpa diiringi dengan kemauan dan kemampuan guru untuk menguasainya akan menjadikan mereka menjadi gagap teknologi. Bahkan, dalam perkembangannya guru-guru menjadi lebih kreatif dengan belajar memanfaatkan aplikasi Kinenmaster untuk membuat video pembelajaran, maupun geogle form dalam pembelajaran BDR di era pandemi Covid-19. Bahkan guru mejadi terbiasa dengan aplikasi Instagram maupun Youtube untuk mengunduh maupun berbagi video pembelajaran.

Daryanto (2017: 3) menyebutkan bahwa dalam pembelajaran abad ke-21 guru harus mampu menguasai lima keterampilan yaitu (1) mampu memberikan fasilitas dan dapat memberikan inspirasi bagi siswa dalam pembelajaran. Guru harus mampu berperan sebagai fasilitator dan sumber inspirator bagi siswanya; (2) membuat rancangan mengembangkan teknik pembelajaran serta asesmen atau penilaian di era digital. Pembelajaran dan penilaian harus dikembangkan dengan pemanfaatan teknologi informasi yang ada; (3) mampu menjadi model bagi siswanya dalam belajar maupun bekerja di era digital. Peran ini menuntut guru jangan sampai gagap teknologi. Guru harus dapat menjadi figur/model dalam penggunaan teknologi digital; (4) mampu memberikan dorongan dan menjadi model tanggung jawab. Guru mampu memberikan motivasi pada siswa dalam belajar; (5) mampu berpartisipasi aktif dalam pengembangan kepemimpinan yang profesional. 
Dewan Teknologi Informasi dan Komunikasi Nasional menyatakan bahwa pembelajaran e-learning dalam hal ini penerapan aplikasi WhatsApp ternyata mempunyai kelebihan dan kekurangan. Kelebihannya antara lain mudah diakses. Aplikasi WhatsApp bahkan sudah banyak dikenal oleh semua kalangan. Biaya lebih terjangkau atau murah, waktu belajar menjadi lebih fleksibel, serta wawasan siswa menjadi lebih luas.

Penerapan WhatsApp juga mempunyai beberapa kekurangan. Pertama, keterbatasan akses internet mengingat kondisi geografis yang berbeda. Kondisi geografis SD Negeri Sembungan di daerah pegunungan terkadang sulit akses internet. Kedua, berkurangnya interaksi antara guru dan siswa. Interaksi antara guru dan siswa yang selama ini berlangsung secara tatap muka sedang interaksi berubah secara daring. Ketiga, pemahaman materi menjadi beragam. Pemahaman materi yang disampaikan secara langsung terkadang siswa sulit memahami materi. Pembelajaran melalui daring akan menyulitkan siswa untuk memahami materi. Antara guru dan siswa dapat berbeda persepsi. Keempat, kurangnya pengawasan dalam proses pembelajaran. Guru maupun orang tua sulit untuk memantau apakah siswa belajar dengan sungguh-sungguh.

Kerjasama guru dan orang tua dalam pendampingan pelaksanaan ekstrakurikuler keagamaan selama BDR sangat diperlukan. Kementerian Pendidikan dan Kebudayaan RI (2017: 4) menyebutkan bahwa pelibatan keluarga dalam pendidikan mempunyai tujuan antara lain untuk meningkatkan peran dan tanggung jawab bersama antara sekolah, keluarga dan masyarakat dalam pelaksanaan pendidikan di sekolah, meningkatkan pelaksanaan penguatan pendidikan karakter. Komunikasi antara orang tua dan guru diarahkan untuk mengatasi dan mencari solusi kendala dalam pelaksanaan BDR. Yang tak kalah penting adalah pengawasan terhadap siswa dalam penggunaan $\mathrm{HP}$ android agar terhindar dari pengaruh negatif yang ada. Siswa harus diberi bekal untuk menggunakan media sosial secara bijaksana dan bertanggung jawab. Sebelum pandemi Covid-19 siswa dibatasi dalam penggunaan HP. Bahkan siswa tidak diperbolehkan membawa HP ke sekolah. Keadaan ini bertolak belakang ketika siswa belajar secara BDR. HP menjadi hal mutlak yang harus dimilki oleh siswa maupun orang tua. Setiap hari siswa tidak 
bisa lepas dari HP android. Selama ini HP menjadi hal yang dikhawatirkan tetapi justru sekarang menjadi hal yang biasa bagi siswa dalam kehidupan sehari-hari.

Sedangkan kendala dari guru dapat diatasi dengan pelibatan teman sejawat untuk memberikan bimbingan pada guru lain dalam pemanfaatan teknologi informasi dalam pembelajaran. Karena dengan cara ini lebih efektif dan memperlihatkan hasil yang baik. Guru yang semula menggunakan fitur WhatsApp sekadar untuk komunikasi, namun sekarang harus menggunakannya untuk pembelajaran. Mau tidak mau mereka harus mampu menguasai dan guru dalam penguasaan TIK dapat terlihat pada tabel di bawah ini.

Tabel 2. Peningkatan Kompetensi Guru dalam Penguasaan Teknologi Informasi

\begin{tabular}{clcccccc}
\hline \multirow{2}{*}{ No } & \multirow{2}{*}{ Nama guru } & \multicolumn{7}{c}{ Kompetensi Yang Dikuasai } \\
\cline { 3 - 7 } & & Office & Excel & Power Point & Instagram & WhatsApp & Youtube \\
\hline 1 & Guru Kelas 1 & $\sqrt{ }$ & $\sqrt{ }$ & $\sqrt{ }$ & $\sqrt{ }$ & $\sqrt{ }$ & $\sqrt{ }$ \\
\hline 2 & Guru Kelas 2 & $\sqrt{ }$ & $\sqrt{ }$ & $\sqrt{ }$ & $\sqrt{ }$ & $\sqrt{ }$ & $\sqrt{ }$ \\
\hline 3 & Guru Kelas 3 & $\sqrt{ }$ & $\sqrt{ }$ & $\sqrt{ }$ & $\sqrt{ }$ & $\sqrt{ }$ & $\sqrt{ }$ \\
\hline 4 & Guru Kelas 4 & $\sqrt{ }$ & $\sqrt{ }$ & $\sqrt{ }$ & $\sqrt{ }$ & $\sqrt{ }$ \\
\hline 5 & Guru Kelas 5 & $\sqrt{ }$ & $\sqrt{ }$ & $\sqrt{ }$ & $\sqrt{ }$ & $\sqrt{ }$ \\
\hline 6 & Guru Kelas 6 & $\sqrt{ }$ & & & & $\sqrt{ }$ & $\sqrt{ }$ \\
\hline 7 & GuruPendidikanAgama & $\sqrt{ }$ & $\sqrt{ }$ & & $\sqrt{ }$ & $\sqrt{ }$ \\
\hline 8 & Guru PJOK & $\sqrt{ }$ & $\sqrt{ }$ & & & \\
\hline
\end{tabular}

Pembelajaran blended learning dalam pelaksanaan ekstrakurikuler keagamaan di SD Negeri Sembungan selama BDR dilaksanakan melalui beberapa tahapan; pertama, persiapan. Tahap persiapan ini dilaksanakan dengan mengidentifikasi kepemilikan HP pada siswa. Melalui pendataan dari guru kelas diperoleh data bahwa terdapat $10 \%$ siswa yang tidak mempunyai $\mathrm{HP}, 70 \% \mathrm{HP}$, milik orang tua, dan hanya $20 \%$ siswa yang memiliki HP, sendiri. Keadaan ini menjadikan blended learning sebagai alternatif pelaksanaan ekstrakurikuler keagamaan. Guru harus memberikan pelayanan pada semua peserta didik, baik yang mempunyai HP, maupun yang tidak memiliki HP,. Peserta didik harus diberikan hak yang sama dalam pendidikan. Setelah dilakukan pemetaan kepemilikan $\mathrm{HP}_{\text {, }}$ guru membentuk kelompok-kelompok siswa. Selanjutnya guru memberikan 
atau menyampaikan tujuan-tujuan yang akan dicapai dalam pelaksanaan kegiatan ekstrakurikuler. Kedua, tahap pelaksanaan. Pada tahap pelaksanaan ini guru memberikan materi, tugas maupun menerima hasil pekerjaan siswa dengan memanfaatkan fitur-fitur yang ada di aplikasi WhatsApp. Adapun fitur whatsapp yang digunakan seperti: chat, video call, unggah gambar maupun video. Berbagai fitur yang terdapat dalam aplikasi WhatsApp sangat relevan dan sangat membantu baik bagi siswa, pendidik, ataupun orang tua untuk melaksanakan pembelajaran baik di dalam kelas ataupun di luar kelas (Yulianti, 2019).

Tahapan pelaksanaan ini mencakup kegiatan daring, luring, dan kegiatan gabungan daring dan luring.



Gambar 1. Blended learning dalam Pembelajaran Ekstrakurikuler Keagamaan

Kegiatan daring dilaksanakan pada saat guru memberikan materi kepada siswa menggunakan aplikasi WhatsApp. Materi diberikan melalui group paguyuban yang dibentuk setiap kelas. Materi-materi yang diberikan dapat berupa buku elektronik, vidio pembelajaran maupun dengan video call secara langsung. Materi kegiatan ekstrakurikuler keagamaan dibedakan materi untuk kelas rendah dan kelas tinggi.

Materi kelas tinggi mencakup baca Al-Qur'an dengan tajwidnya, sedangkan materi kelas rendah yaitu iqro. Siswa SD di akhir pendidikan ditargetkan untuk khatam membaca Al-Qur'an. Siswa juga hafal surat An-Nas sampai Ad Duha. Selain itu, juga diajari tata cara salat lima waktu agar dapat menjalankan salat lima waktu.

Materi kegiatan ekstrakurikuler keagamaan di SD Negeri Sembungan lebih terfokus kepada membaca Al-Qur'an, tata cara salat lima waktu dan praktek dalam kehidupan sehari-hari. Materi ini diberikan mengingat $100 \%$ atau semua siswa beragama Islam. Sebaran materi untuk tiap kelas 
sudah ditentukan oleh Dinas Pendidikan Pemuda dan Olahraga. Kompetensi yang harus dikuasai oleh siswa tiap kelas berbeda-beda. Hal ini disesuaikan dengan tingkat umur dan kemampuan. Adapun sebaran kompetensi dapat dilihat pada tabel di bawah ini.

Tabel 2. Kompetensi yang Harus Dikuasai oleh Siswa dalam Pelaksanaan Ekstrakurikuler Keagamaan

\begin{tabular}{|c|c|c|c|c|c|c|c|}
\hline No & Kompetensi & Kelas 1 & Kelas 2 & Kelas 3 & Kelas 4 & Kelas 5 & Kelas 6 \\
\hline 1 & $\begin{array}{l}\text { SD Khatam } \\
\text { Al-Qur'an }\end{array}$ & Iqra jilid 1-3 & $\begin{array}{l}\text { Iqra jilid 4- } \\
6\end{array}$ & Juz 1-7 & Juz 8-15 & Juz 16-24 & $\begin{array}{l}\text { Juz 25- } \\
30\end{array}$ \\
\hline 2 & $\begin{array}{l}\text { Hafal Al- } \\
\text { Qur'an } \\
\text { surat An } \\
\text { Nas } \\
\text { surat } \\
\text { Dhuha } \\
\text { Dhuha }\end{array}$ & $\begin{array}{l}\text { Surat An Nas, } \\
\text { surat Al-Falaq, } \\
\text { surat Al-lkhlas, } \\
\text { dan surat Al } \\
\text { Lahab }\end{array}$ & $\begin{array}{l}\text { Surat An } \\
\text { Nas, surat } \\
\text { al Kafirun, } \\
\text { surat Al } \\
\text { kautsar } \\
\text { dan surat } \\
\text { Al Maun }\end{array}$ & $\begin{array}{l}\text { Surat Al } \\
\text { Quraisy, } \\
\text { surat Al Fil, } \\
\text { surat al } \\
\text { Humayah, } \\
\text { dan surat } \\
\text { Al Asr }\end{array}$ & $\begin{array}{l}\text { Surat At } \\
\text { Takasur, } \\
\text { surat Al } \\
\text { qoriah, } \\
\text { surat Al } \\
\text { Adiyat, } \\
\text { dan surat } \\
\text { AlZalzalah }\end{array}$ & $\begin{array}{l}\text { Surat } \mathrm{Al} \\
\text { Bayinah, } \\
\text { surat Al } \\
\text { Qadr, } \\
\text { surat } \mathrm{Al} \\
\mathrm{A}^{\prime} \text { la dan } \\
\text { surat At } \\
\text { Tin }\end{array}$ & $\begin{array}{l}\text { Surat Al } \\
\text { Insyrah } \\
\text { dan } \\
\text { surat } \\
\text { Adhuha }\end{array}$ \\
\hline 3 & $\begin{array}{l}\text { Memaham } \\
\text { i tata cara } \\
\text { salat dan } \\
\text { melaksana } \\
\text { kan salat } 5 \\
\text { (lima) } \\
\text { waktu }\end{array}$ & $\begin{array}{l}\text { Gerakan } \\
\text { salat, } \\
\text { takbiratulikr } \\
\text { am, surat } \mathrm{Al} \\
\text { Fathah, doa } \\
\text { duduk di } \\
\text { antara dua } \\
\text { sujud }\end{array}$ & $\begin{array}{l}\text { Gerakan } \\
\text { salat, doa } \\
\text { iftitah, doa } \\
\text { sujud dan } \\
\text { ruku' }\end{array}$ & $\begin{array}{l}\text { Gerakan } \\
\text { salat, doa } \\
\text { duduk } \\
\text { atahiyat } \\
\text { terakhir, } \\
\text { doa } \\
\text { sebelum } \\
\text { salam, dan } \\
\text { doa salam }\end{array}$ & $\begin{array}{l}\text { Pembias } \\
\text { aan } \\
\text { melaksa } \\
\text { nakan } \\
\text { gerakan } \\
\text { salat, } \\
\text { bacaan } \\
\text { salat } \\
\text { secara } \\
\text { baik dan } \\
\text { benar }\end{array}$ & $\begin{array}{l}\text { Pembias } \\
\text { aan } \\
\text { melaksa } \\
\text { nakan } \\
\text { gerakan } \\
\text { salat, } \\
\text { bacaan } \\
\text { salat } \\
\text { secara } \\
\text { baik dan } \\
\text { benar }\end{array}$ & $\begin{array}{l}\text { Pembias } \\
\text { aan } \\
\text { melaksa } \\
\text { nakan } \\
\text { gerakan } \\
\text { salat, } \\
\text { bacaan } \\
\text { salat } \\
\text { secara } \\
\text { baik dan } \\
\text { benar }\end{array}$ \\
\hline
\end{tabular}

Materi tugas-tugas selama pembelajaran BDR yang diberikan oleh guru kepada siswa juga disampaikan melalui grup WhatsApp paguyugan kelas. Jika siswa atau orang tua siswa kurang memahami tugas maupun materi yang disampaikan oleh guru dapat menanyakan secara langsung melalui fitur chat yang ada atau bertanya secara langsung melalui fitur panggilan yang ada di WhatsApp Kesulitan yang sering dihadapi oeh siswa maupun orang tua adalah adanya pemahaman terhadap materi. Pemahaman materi terkadang antara satu siswa dengan siswa yang lain berbeda. Daya serap siswa juga berbeda, mengingat siswa mempunyai karakteristik yang berbeda-beda pula. Ada siswa yang mempunyai tipe visual, ada yang bertipe audio, namun ada pula yang bertipe audio visual.

Terkait dengan hal tipe-tipe belajar anak tersebut guru harus mampu memberikan materi yang dapat memudahkan siswa untuk memahaminya. Menurut 
Hariadi (2020) menyatakan bahwa dalam pembelajaran guru juga harus mampu menciptakan suasana belajar yang bermakna dan menyenangkan. Materi dapat bersifat audio yaitu berupa rekaman, dapat berupa visual seperti teks atau tulisan, ataupun dapat bersifat audio visual seperti vidio pembelajaran. Dengan beragamnya bentuk materi maka materi akan mudah dipelajari dan dipahami sehingga hasil belajar dapat sesuai dengan tujuan.

Penyediaan sarana untuk pelaksanaan ekstrakurikuler keagamaan mutlak harus ada. Sarana yang diperlukan seperti ketersediaan buku iqra, mushaf Al-Qur'an, peraga iqra, dan buku-buku tajwid. Pembiayaan pengadaan sarana tersebut juga dibiayai secara khusus dari dana APBD Pemda Kulon Progo. Pada masa pandemi Covid 19 ini buku-buku tersebut dipinjamkan ke siswa untuk belajar di rumah. Tak kalah penting adalah ketersediaan sarana internet di sekolah. Dengan sarana internet yang memadai akan memudahkan guru untuk melakukan pembelajaran dengan blended learning.

Langkah selanjutnya siswa dengan bantuan/bimbingan orang tua memahami materi dan mengerjakan tugas secara luring. Materi dari guru dapat dilihat, dibaca sesuai dengan waktu yang tersedia bagi siswa dan orang tua. Mengingat terkadang orang tua mempunyai waktu luang setelah pulang kerja. Dalam tahap pengerjaan tugas ini banyak kendala yang dihadapi antara lain. Pertama, orang tua tidak memiliki kompetensi atau pemahaman terhadap materi yang diberikan guru. Orang tua merasakan kesulitan dalam memberikan bimbingan kepada anaknya. Orang tua siswa 75\% berlatar belakang pendidikan SMP atau sederajat. Pemahaman mereka tentang materi keagamaan juga masih kurang. Untuk mengatasi ini orang tua memanfaatkan grup paguyuban untuk bertukar pikiran dan saling belajar. Mereka juga dapat bertanya langsung kepada guru pembimbing tentang materi yang belum dipahami. Kegiatan ini bersifat daring. Orang tua dapat memanfaatkan fitur WhatsApp. Kedua, keterbatasan perangkat hp android. Tidak semua siswa memilki HP android. Untuk mengatasi permasalahan ini tugas diberikan secara luring dengan cara wali mengambil tugas ke sekolah dan bila telah selesai dikumpulkan kembali ke sekolah. Namun ada pula HP android digunakan secara bergantian, mengingat 
ada siswa yang kakak beradik dengan tingkat kelas yang berbeda. Bahkan ada satu HP yang digunakan bertiga, karena ada yang di kelas 1, 2, dan 3. Selain itu juga ada kejadian unik yaitu terdapatnya dua pasang siswa kembar 2 dan kembar 3.

Setelah tugas selesai dikerjakan siswa mengirim tugas tersebut melalui grup WhatsApp paguyuban kelas. Baik itu dengan bantuan/ bimbingan orang tua terutama siswa kelas rendah, maupun secara mandiri bagi siswa kelas tinggi. Bagi siswa yang tidak memilki HPandroid, orang tua mengantar hasil pekerjaan putra-putrinya ke sekolah. Untuk tugas yang berupa hafalan dipantau dengan buku catatan kemajuan/catatan prestasi.

Penilaian terhadap pelaksanaan ekstrakurikuler keagamaan dilakukan dengan penilaian sikap, penugasan, portofolio dan bentuk penilaian yang lain. Dari hasil pengamatan perangkat penilaian yang dibuat oleh guru pembimbing ekstrakurikuler dapat diperoleh data ketuntasan siswa dalam melaksanakan ekstrakurikuler keagamaan. Hasil dari penilaian disampaikan kepada wali murid maupun stakeholder yang ada yaitu pengawas pembina maupun Dinas Pendidikan Pemuda dan Olah Raga selaku pemberi dana/ honor bagi pembimbing ekstrakurikuler. Kegiatan ekstrakurikuler keagamaan ini sumber dananya dari APBD Pemda Kulon Progo. Maka sekolah berkewajiban memberikan laporan pelaksanaan ke Dinas Pendidikan Pemuda dan Olahraga Kabupaten Kulon Progo. Sebelum pandemi Covid-19, sekolah berkewajiban menyampaikan foto kegiatan ekstrakurikuler melalui apliaksi SIM Pendekarku. Aplikasi SIM Pendekarku ini digunakan untuk memantau pelaksanaan kegiatan ekstrakurikuler keagamaan secara daring.

Majid (2011: 187) menyatakan bahwa penilaian yang dilakukan oleh guru harus ditujukan kepada fungsi dan tujuan yaitupenelusuran, penilaian ditujukan untuk melakukan kegiatan penulusuran agar pembelajaran tetap sesuai dengan rencana yang telah ditetapkan sebelumnya; pengecekan. Di sini penilaian difungsikan untuk mengecek kompetensi yang telah dikuasai siswa maupun kompetensi yang belum dikuasai siswa. Pencarian, fungsi pencarian dimaksudkan agar penilaian dapat menentukan kelemahan atau kekurangan yang menyebabkan proses pembelajaran tidak berjalan 
dengan baik. Kelemahan atau kekurangan tersebut segara dapat diatasi sehingga pembelajaran berjalan dengan baik, penyimpulan, penilaian harus mampu mendapatkan kesimpulan apakah siswa sudah menguasai kompetensi yang harus dikuasai dalam tujuan pembeajaran.

Penilaian dilakukan dengan berbagai macam cara dan teknik. Guru memberikan tugas kepada siswa secara daring. Siswa mengerjakan tugas secara luring. Setelah tugas selesai dikerjakan, tugas tersebut dikirim secara daring maupun luring. Ketika guru harus menilai dengan pengamatan, seperti saat pelafalan pada saat membaca iqra. Guru memberikan tugas secara daring, Siswa dibantu orang tua merekam kegiatan membaca iqra. Rekaman video kemudian dikirimkan kepada guru secara daring melalui aplikasi WhatsApp. Guru melakukan penilaian terhadap video yang dikirim oleh wali murid tersebut.

Selain teknik tersebut di atas, penilaian juga dilakukan dengan cara video call. Sebagai contoh ketika guru akan menyimak benar salahnya bacaan tajwid dari siswa saat menghafal surat-surat pendek dalam AlQur'an. Teknik ini memungkinkan guru dapat memberikan langkah pembetulan jika ada kesalahan dalam pelafalannya. Dengan pembetulan secara langsung maka siswa akan berusaha untuk memperbaikinya. Berbeda dengan teknik siswa mengumpulkan rekaman audio maupun video karena pembetulan tidak dapat dilakukan secara langsung. Kegiatan ini berlaku untuk semua siswa, baik kelas rendah maupun kelas tinggi.

Lantas bagaimana dengan anak yang tidak memiliki HP android?. Pada kasus semacam ini maka guru melakukuan aktifitas guru kunjung. Aktifitas ini memungkinkan guru untuk melakukan kunjungan ke rumah siswa yang tidak memilki HP. Guru dapat memberikan tugas secara langsung. Namun bisa juga guru hanya memantau maupun mengecek sejauh mana siswa mampu memahami materi yang diberikan, mugkin juga tugas sudah diambil sebelumnya oleh orang tua ke sekolah secara langsung. Pada saat kunjungan ke rumah siswa, guru dapat pula melaksanakan penilaian secara langsung. Kegiatan guru kunjung ini hanya dilakukan kepada siswa yang tidak memiliki HP. Dan dalam kunjungan ini juga tetap memperhatikan protokol kesehatan mengingat masih dalam situasi pandemi Covid-19. 
Hasil penilaian juga dijadikan acuan bagi guru untuk menentukan langkah perbaikan maupun pengayaan. Bagi siswa yang belum tuntas diberikan bimbingan khusus agar tuntas. Siswa yang telah tuntas diberikan pengayaan. Pemberian perbaikan dan pengayaan dapat meningkatkan pelayanan terhadap peserta didik. Dari data yang diperoleh dari guru kelas dan guru pembimbing ekstrakurikuler, diketahui siswa kelas 1 99\% tuntas, kelas 2 ketuntasan sebesar 97\%, kelas 3 ketuntasan sebesar 98\% tuntas, siswa kelas 4 ketuntasan sebesar $100 \%$, kelas 5 ketuntasan 100\%, dan siswa kelas 6 ketuntasan $100 \%$.

Seperti telah disebutkan di bagian sebelumnya bahwa ketuntasan untuk siswa kelas 1 s.d kelas 2 yaitu menguasai iqro, hafalan surat-surat pendek dalam Al-Qur'an, gerakan salat, dan pelaksanaannya dalam kehidupan sehari-hari. Kelas 4 s.d 6 harus tuntas membaca Al-Qur'an dari juz 1-8 (kelas 3), juz 8- 15 (kelas 4), juz 16-24 (kelas 5), dan juz 25-30 (kelas 6). Dengan kegiatan ekstrakurikuler ini diharapkan siswa yang beragama Islam dapa khatam Al-Qur'an setelah lulus dari pendidikan di Sekolah Dasar.



Gambar 2. Alur Blended learning dalam Pembelajaran Ekstrakurikuler Keagamaan

Walaupun telah disebutkan sebelumya bahwa dalam pelaksanan BDR kendala utama adalah kepemilikan HP dan kemampuan orang tua yang terbatas, ternyata masih terdapat kendala lain. Kendala lain dalam pelaksanaan pembelajaran keagamaan dalam masa BDR ini adalah keterbatasan kuota. Dalam pembelajaran blended learning lebih banyak menggunakan kuota, terutama pada saat pembelajaran dalam bentuk daring. Baik itu pada saat mengunduh materi Materi yang disampaikan guru melalui WhatsApp 
baik itu berupa dokumen, video, maupun yang lain memerlukan kuota. Demikian pula pada saat siswa mengirimkan tugas yang harus dikumpulkan secara daring juga memerlukan kuota. Kuota internet menjadi masalah karena orang tua merasa keberatan membelinya. Terlebih $75 \%$ wali murid yang berprofesi sebagai buruh. Keterbatasan kuota ini dapat diatasi dengan pemberian bantuan kuota. Pemberian bantuan kuota diberikan oleh sekolah melalui anggaran BOS. Bantuan kouta juga diusulkan pihak sekolah melalui Dapodik. Pengimputan data Dapodik ditujukan untuk memperoleh bantuan kuota yang deberikan oleh Kemendikbud.

Penerapan blended learning pada pelaksanaan ekstrakurikuler keagamaan memberikan manfaat yaitu (1) kegiatan ekstrakurikluler yang telah diprogramkan oleh sekolah dapat berjalan sesuai rencana. Kegiatan ekstrakurikuler keagamaan dalam masa pandemi harus tetap dijalankan mengingat kegiatan ini sudah dianggarkan dan didanai oleh APBD Kabupaten Kulon Progo; (2) pendidikan karakter yang telah dicanangkan oleh pemerintah dapat berjalan dengan baik, melalui kegiatan ini pendidikan karakter tetap berjalan dengan baik; (3) segala permasalahan yang dihadapi dapat terselesaikan dengan baik; (4) siswa mendapatkan haknya untuk belajar materi keagamaan walau dalam keadaan pandemi Covid-19 yang tidak memungkinkan untuk belajar secara tatap muka; (5) secara tidak langsung siswa, guru dan orang tua dapat meningkat kamampuannya dalam penguasaan teknologi.
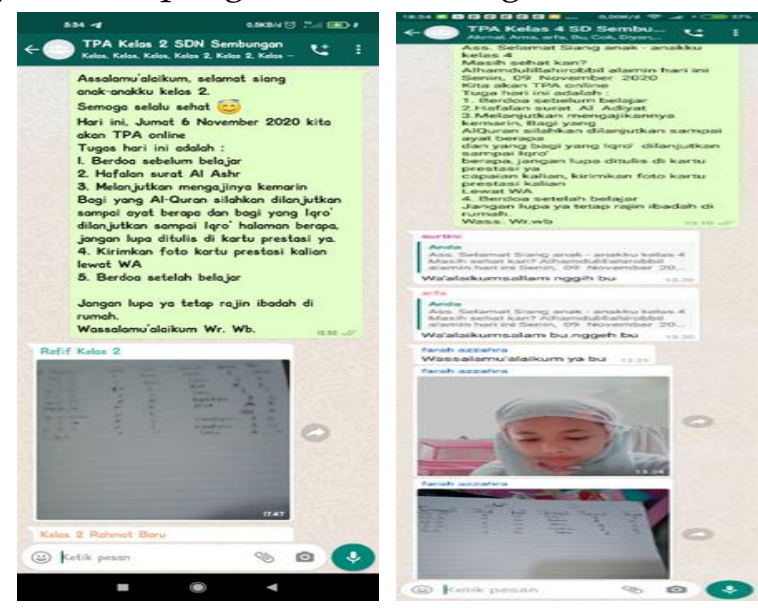

Gambar 3. Tangkapan Layar Kegiatan BDR Ekstrakurikuler Keagamaan dengan Aplikasi WhatsApp 


\section{Penutup}

Pelaksanaan BDR dalam kegiatan ekstrakurikuler keagamaan di SD Negeri Sembungan dapat terlaksana. Kendala rendahnya penguasaan teknologi informasi dapat diatasi dengan penerapan pembelajaran blended learning berbasis aplikasi WhatsApp. Tahapan pelaksanaan blended learning pada kegiatan ekstrakurikuler keagamaan diawali dengan pemberian tugas secara daring. Tugas tersebut kemudian dikerjakan oleh siswa dengan mendapatkan bimbingan dari orang tua masing-masing. Pengerjaan tugas dilaksanakan secara luring. Pengumpulan tugas dapat dilaskanakan secara daring maupun luring.

Kegiatan akhir berupa penilaian juga dilaksanakan secara daring maupun luring, dan kombinasi daring dan luring. Pembelajaran blended learning dilaksanakan dengan mengoptimlakan keterlibatan teman sejawat. Keterlibatan teman sejawat atau teman seprofesi dapat memberikan peningkatan kompetensi penguasaan teknologi informasi. Teknologi informasi khususnya apliaksi whatsapp dengan segala fitur-fitur yang ada dioptimalkan untuk menunjang pelaksanaan kegiatan ekstrakurikuler keagamaan.

Seiring dengan perkembangannya, guru menjadi termotivasi dengan penerapan aplikasi lain seperti Instagram dan Youtube yang mereka manfaatkan untuk pembelajaran. Untuk menghadapi pembelajaran BDR selanjutnya, guru dapat menerapkan atau mengaplikasikan platform seperti Geogle Form, Jogja Belajar, dan platform lain baik yang berbayar maupun tidak berbayar.

\section{Ucapan Terimakasih}

Ucapan terima kasih kami sampaikan kepada Bapak dan Ibu guru SD Negeri Sembungan yang telah dengan tekun dan ikhlas untuk melaksanakan pembelajaran ekstrakurikuler keagamaan walau di tengah situasi pandemi covid19. Tak lupa penulis sampaikan apresiasi kepada siswa yang telah melaksanakan kegiatan pembelajaran dengan baik, serta kepada orang tua wali murid juga kami sampaikan terima kasih atas keikhlasannya dalam mebimbing dan menamani putra-putrinya.

Akhirnya ucapan terima kasih juga kami sampaikan kepada Dinas Pendidikan Pemuda dan Olahraga Kabupaten Kulon Progo karena dengan 
bantuan dana yang diberikan untuk memberikan honor bagi guru/ pembimbing ekstrakurikuler keagamaan di SD Negeri Sembungan.

\section{Daftar Referensi}

Cheruman, Uwes Anis. (2013). Merancang Model Blended Learning. Jurnal Teknodik. Edisi Tahun 2013.399-409

Daryanto. (2017). Pembelajaran Abad 21. Yogyakarta: Gava Media.

Dewan Teknologi Informasi dan Komunikasi Nasional, "Empat Kelebihan dan Kekurangan Dalam Menerapkan E-Learning" dalam http://www.wantiknas.go.idberita/empat-kelebihan-dankekurangan-dalam-menerapkan-e-learning, diunduh 8 Juli 2020.

Dinas Pendidikan Pemuda dan Olahraga Kabupaten Kulon Progo. (2017). Buku Pedoman Pelaksanaan Penguatan Pendidikan Karakter.

Hariadi, Sutrisno. Pengembangan Teks Wawanrembug Berbasis Blended Learning pada Siswa Kelas VIII. Jurnal Dikdatika Pendidikan Dasar, 4(1). 3958. doi: 10.26811/didaktika.v4il.125

Kementrian Pendidikan dan Kebudayaan. (2017). Petunjuk Teknis Pelibatan Keluarga pada Penyelenggaraan Sekolah Dasar. Jakarta

Majid, Abdul. (2011). Perencanaan Pembelajaran. Mengembangkan Standar Kompetensi Guru. Bandung: Remaja Rosda Karya.

Mulyasa. (2009). Menjadi Kepala Sekolah Profesional. Bandung: Remaja Rosda Karya.

Peraturan Bupati Nomor 65 Tahun 2017 Tentang Pedoman Pelaksanaan Penguatan Pendidikan Karakter

Seameo Ceccep. Pembelajaran Jarak Jauh dalam Masa PSBB. [powerpoint slides] diakses dari Materi Webinar 21 Mei 2020. Seameo Ceccep: https://seameo-ceccep.org/live/200708.php

Surat Edaran Menteri Pendidikan dan Kebudayaan Nomor 4 Tahun 2020. Pelaksanaan Kebijakan Pendidikan Dalam Masa Darurat Penyebaran Coronazirus Disease (COVID-19). 24 Maret 2020. Jakarta.

Suyono. (2017). Belajar dan Pembelajaran. Bandung: Remaja Rosda Karya.

Undang-Undang Nomor 14 Tahun 2005 Tentang Guru dan Dosen. 30 Desember 2005. Lembaran Negara Republik Indonesia Tahun 2005 Nomor 157. Jakarta 
Yulianti, Yuli. (2019). Metode Tutor Sebaya Berbantuan Whatsapp Berbantuan Whatsapp Untuk Meningkatkan Hasil Uji Coba Ujian Nasional di SMK Negeri 1 Tanjugpandan. Indonesian Digital Journal of Mathematics and

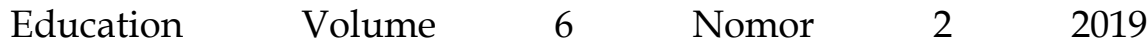
http://p4tkmatematika.kemdikbud.go.id/journals/index.php/idealmathedu

Yusrizal, Y., \& Hanif, K. (2017). Increasing of Students' Motivation in Learning Physics Through the Use of Computer Simulation Media Viewed From Parents' Employment Background. Jurnal Ilmiah Peuradeun, 5(2), 201-212. doi:10.26811/peuradeun.v5i2.129 